\title{
高温が岩石の強度・変形特性，熱物性， クリープ特性に及ぼす影響十
}

\section{木 下 尚 樹* 稲 田 善 紀* \\ Effects of High Temperature on Strength, Deformation, Thermal Properties and Creep of Rocks}

by

\author{
Naoki KInoshita* and Yoshinori INADA *
}

\begin{abstract}
The authors have proposed and discussed temporary storage of heated water in openings excavated in rock moun-tain from the viewpoints of multiple-utilization of land, environmental safeguards, energy conservation, etc. When used for heated-water storage, the rock mass around the openings will receive the effects of the heated water. In this study, for obtaining physical properties used for analysis of thermal behavior of rock mass around openings, the effect of the difference between Wet (the water-retaining condition) and Dry and physical properties on strength, deformation characteristics and thermal properties at high temperatures were examined using 5 kinds of rock (granite, andesite, sandstone, tuff and mudstone). In addition, a uniaxial compression creep test at high temperatures of the rock was also carried out, then compared with the creep property at room temperature. The calculation of various constants on the creep was tried using Burgers model. In outline, the results show the strength of Wet rock is smaller than that of Dry, and strength lowers with the rise in the temperature, the lowering proportion being larger in Wet. The elastic modulus of tuff and mudstone are smaller than those of granite, andesite and sandstone. In particular, the lowering proportion at high temperatures is also large in Wet. Thermal property can be considered almost constant for practical use, and the effect of the temperature is small. As the difference of Dry and Wet is large, it seems that the effect of pore water is large. Especially, the tendency is remarkable in tuff and mudstone in which porosity is large. Temperature influences the uniaxial compression creep property of rock.
\end{abstract}

Key words : Rock, Strength, Deformation, Thermal properties, Creep, High temperatures, Heated water storage, Opening

\section{1 緒言}

エネルギーの有効利用の観点から, ごみ焼却時に発生 する廃熱を利用して, 水を熱水に変え, 各家庭への給湯 や地域暖房等多目的に利用する「熱水貯蔵システム」を 筆者らは提案し, 検討を行ってきている.1), 2)この方法は 地方の山村や町で問題となっている過疎化現象の対応策 として地域の活性化につながり, 行政面から見てもこれ まで困難であったごみ焼却場の立地の可能性も高まると 考えられる。熱水を利用する場合，一日の時間帯や季節 による使用量の変動に関係なく安定した供給を行うため, 一時的な眝蔵施設が必要となってくる。の一つの方法 として, 土地の立体的有効利用, 環境保全等で有利であ ると考えられる地山岩盤内に設けた空洞内に熱水を貯蔵 する方法を提案している。 この場合, 空洞周辺岩盤には 熱水を貯蔵することにより熱応力が発生するため, 空洞 の安定性や熱的挙動を検討して扔く必要がある.

これまでの研究により, 温度履歴を受けた岩石の強 度・変形特性について, 実験方法を提案し, 結果を報告 した。また, 実験結果を用いて空洞周辺の熱的な挙動を 解析により検討してきた.1,2)
本研究では，さらに熱的挙動を検討するための基礎資 料とするために, 典型的と考えられる 5 種類の岩石（花 崗岩, 安山岩, 砂岩, 凝灰岩, 泥岩) を用い, 物理的性 質や含水状態の違いが，高温下に打ける強度・変形特性 および熱物性値に及ぼす影響を実験により求め考察した。

また，これまでの熱水の地山岩盤内貯蔵についての検 討の結果，空洞周辺岩盤には空洞内の熱水を熱源として 非定常の温度分布が生じ, これに伴い熱応力が発生して 空洞の安定性に影響を及ぼし, さらら，長期に渡り熱応 力が発生するため, 空洞の長期の安定性を検討するため にはクリープ変形も考慮する必要があると考えられる. そのため, 本研究では高温下に打ける岩石の一軸圧縮ク リープ試験も行い，常温下のクリープ特性と比較した。 また, Burgers model を用いてクリープに関する諸定数 の算定を試みた。

\section{2 高温下における種々の岩石の強度・変形特性}

\section{$2 \cdot 1$ 実験に用いた岩石試料}

実験に用いた岩石は, 花崗岩（愛媛県今治市産）, 安 山岩（愛媛県久万高原町産）, 砂岩（福岡県大牟田市産）, 凝灰岩（栃木県宇都宮市産）打よび泥岩（神奈川県相模

$\dagger \quad$ 原稿受理 平成 17 年 8 月 11 日 Received Aug. 11, 2005

* 正 会員 愛媛大学工学部環境建設工学科 ７790-8577 松山市文京町, Dept. of Civil and Environmental Eng., Ehime Univ., Bunkyo-cho, Matsuyama, 790-8577 
原市産）である. 各岩石の物理的性質を Table 1 に示す. 花崗岩の空隙率が約 1\%, 安山岩が約 3\%, 砂岩が約 8\% と比べて, 凝灰岩打よび泥岩の空隙率はそれ先れ約 $37 \%$ および $39 \%$ と大きい.

一般に岩石には節理や層理が存在しており, 力学的特 性を調べる際には力学的異方性を考慮する必要がある. 花崗岩には一般的にほぼ直交する 3 つの潜在的亀裂面が 存在し, rift plane, grain plane, hardway plane と分類さ れている.3.本研究でもこの分類に従うものとし，岩石ブ ロックの弾性波伝播速度を測定することによりこれらの 面を推定し， hardway planeに垂直となる方向にコアド リルで試料を採取した。また，堆積岩である砂岩，凝灰 岩执よび泥岩についても, 岩石ブロックの弾性波伝播速 度の測定により堆積層を推定し, これに対して平行にな るようにコアドリルで採取した。これらの岩石を一軸圧 縮試験用には $\phi 3 \times 6 \mathrm{~cm}$, 圧裂引張試験用には $\phi 3 \times 3 \mathrm{~cm}$ に成形した。端面の平行度および平坦度には特に留意し， $5 / 100 \mathrm{~mm}$ 以内とした。また, 試料は以下に示す 2 通り の方法で処理した。

(1) 室内で 1 週間以上自然乾燥した後, デシケータ内 でさらに一週間乾燥した。

(2) (1)の状態のものを蒝留水を満たしたデシケータ内 で真空ポンプにより 5 時間脱気した。

以後，(1)の状態のものを “Dry”, (2)の状態のものを “Wet” と呼ぶこととする.

\section{$2 \cdot 2$ 圧縮強度および引張強度}

圧縮強度の測定装置の概念図を Fig. 1 に示す．Dry の 供試体については空気中で, Wet の供試体については蒝 留水に浸した状態で, 高温炉内の温度を $15^{\circ} \mathrm{C}, 60^{\circ} \mathrm{C}$ およ

Table 1 Physical properties of rocks used for the tests.

\begin{tabular}{crrrrr}
\hline rocks & $\begin{array}{c}\text { moisture } \\
\text { porosity } \\
\text { content } \\
\text { ratio } \\
(\%)\end{array}$ & $\begin{array}{c}\text { degree } \\
\text { of } \\
\text { saturation } \\
(\%)\end{array}$ & $\begin{array}{c}\text { bulk } \\
\text { specific } \\
\text { gravity }\end{array}$ & $\begin{array}{c}\text { true } \\
\text { specific } \\
\text { gravity }\end{array}$ \\
\hline granite(dry) & 0.8 & 0.1 & 28.5 & 2.65 & 2.67 \\
granite(wet) & 0.8 & 0.2 & 81.3 & 2.65 & 2.67 \\
andesite(dry) & 5.6 & 0.9 & 41.0 & 2.55 & 2.67 \\
andesite(wet) & 5.6 & 1.9 & 88.3 & 2.59 & 2.67 \\
sandsotne(dry) & 8.1 & 1.5 & 16.8 & 2.40 & 2.62 \\
sandsotne(wet) & 8.1 & 3.4 & 96.9 & 2.49 & 2.62 \\
tuff(dry) & 37.1 & 1.4 & 5.8 & 1.56 & 2.45 \\
tuff(wet) & 37.1 & 24.0 & 99.6 & 1.91 & 2.45 \\
mudstone(dry) & 39.4 & 1.3 & 5.4 & 1.63 & 2.69 \\
mudstone(wet) & 39.4 & 21.1 & 99.6 & 2.02 & 2.69 \\
\hline
\end{tabular}

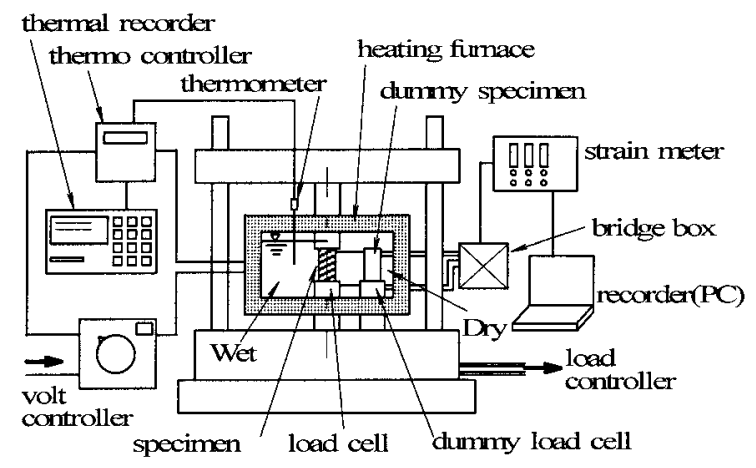

Fig. 1 Schematic diagram of strength test.
び $100^{\circ} \mathrm{C}$ 各温度で保温し, 各温度における一軸圧縮試 験を実施した。またWetの実験に打いては蒸留水が沸騰 する直前まで加熱したため, 実際は $100^{\circ} \mathrm{C}$ 未満の $98^{\circ} \mathrm{C}$ 程 度であったが，ここではこの温度を便宜上 $100^{\circ} \mathrm{C}$ と呼ぶ ことにする。 また，供試体を所定の温度に加熱する場合， 熱衝撃を防ぐ必要がある. 別の研究から供試体の寸法が この程度のものであれば, 昇温速度が $3.3^{\circ} \mathrm{C} / \mathrm{min}$ 以内で あれば熱衝撃が生じないことが報告されており 年ここで は $1^{\circ} \mathrm{C} / \mathrm{min}$ で昇温した。さらに供試体の表面から中心ま で一定の温度にする必要があるが，供試体の寸法がこの 程度であれば理論上保温時間約 20 分で中心部まで温度 が及ぶことが報告されている.5)ここでは設定温度と供試 体表面, 中心の温度差が $\pm 0.2^{\circ} \mathrm{C}$ 以内で安定していると 確認できる時間として，60 分間保温した後に実験を行っ た。荷重速度は花崗岩, 安山岩执よび砂岩については $0.7 \mathrm{MPa} / \mathrm{s}$ とし, 強度が花崗岩などと比べ小さい, 凝灰 岩は $0.5 \mathrm{MPa} / \mathrm{s}$ ，泥岩については $0.2 \mathrm{MPa} / \mathrm{s}$ とした。な お, 以下に述べる実験においては試験回数は各条件とも 最低 5 回とし, 結果を平均値で示すこととした。 圧縮試 験の結果を Fig. 2 に示す.いずれの岩石においても温度 の上昇に伴い值が低下している。これは温度上昇に伴う 岩石を構成する鉱物粒子の熱膨張率の不一致によってマ イクロクラックが発生し，また潜在的マイクロクラック が拡大されることが原因であると考えられる。いずれの 岩石に打いても Dry よりも Wetの方が值は小さい。これ は供試体表面から間隙内に水が侵入したことにより，荷 重をかけた際，間隙水が水圧として働き破壊を促進させ たことや，岩石を構成する主成分の Si-O が引張応力下で は原子間結合が引き延ばされ，結合が不安定な活性化さ れた状態になるため, 水と反応しやすく, 反応により結合 が切断される応力腐食 ${ }^{6}$ などが原因と考えられる。 また， デシケータ内で乾燥させた Dry の岩石であっても，間隙 内に必ず水分が残留している。こうした水分は構成鉱物 粒子の境界付近で表面張力や粒子の吸着力により保持さ

\begin{tabular}{|c|c|}
\hline-1 granite(dry) & - granite(wet) \\
\hline$-\square-$ andesite(dry) & $\rightarrow$ andesite(wet) \\
\hline$\prec$ sandstone $(\mathrm{dry})$ & $\longrightarrow$ sandstone(wet) \\
\hline$\triangle \backsim$ tuff(dry) & $\smile$ tuff(wet) \\
\hline$\rightarrow-$ mudstone(dry) & $\checkmark \boldsymbol{V}$ mudstone(wet) \\
\hline
\end{tabular}

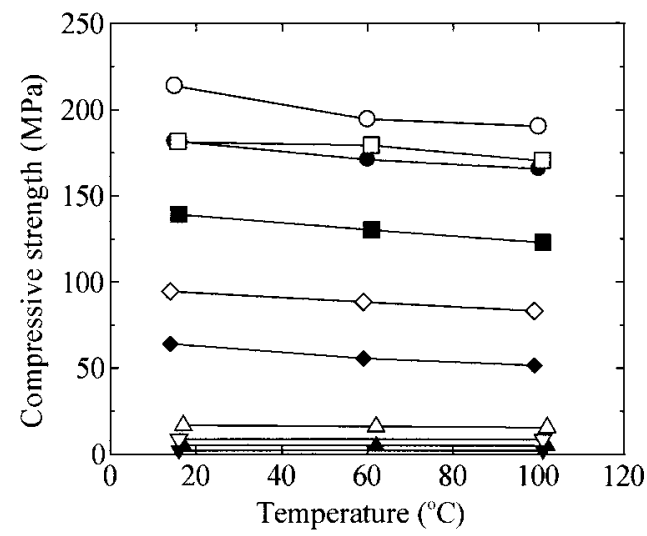

Fig. 2 Compressive strength of rocks at high temperature. 
れており，大気圧に対してサクションと呼ばれる負の圧力 を持ち構成鉱物粒子の結合力として作用する.7)このこと もDryの方が強度が大きいことの原因と考えられる.

次に高温下に打ける各岩石の圧裂引張強度を比較した ものを Fig. 3 に示す。昇温速度および保温時間は圧縮試 験の場合と同様にした。 また，荷重速度については花崗 岩, 安山岩および砂岩については $50 \mathrm{~N} / \mathrm{s}$ とし, 軟岩であ る凝灰岩执よび泥岩はともに $20 \mathrm{~N} / \mathrm{s}$ とした。いずれの岩 石に打いても温度の上昇に伴い值が低下している。これ も圧縮強度と同様に温度上昇に伴う構成鉱物粒子の熱膨 張率の不一致によりマイクロクラックの発生および拡大 が原因であると考えられる。またいずれの岩石において もDryよりも Wetの方が值は小さく，これについても圧 縮強度と同様に間隙水の影響, 応力腐食およびサクショ ン効果などの影響が考えられる。

\section{$2 \cdot 3$ 接線弾性係数およびポアソン比}

圧縮強度試験の際に供試体表面に貼り付けたひずみ ゲージにより得られる応力ーひずみ曲線から, 破壊応力 の $30 \%$ 付近の接線弾性係数打よびポアソン比を求めた結 果を Fig. 4 および Fig. 5 に示す. 接線弾性係数は温度の

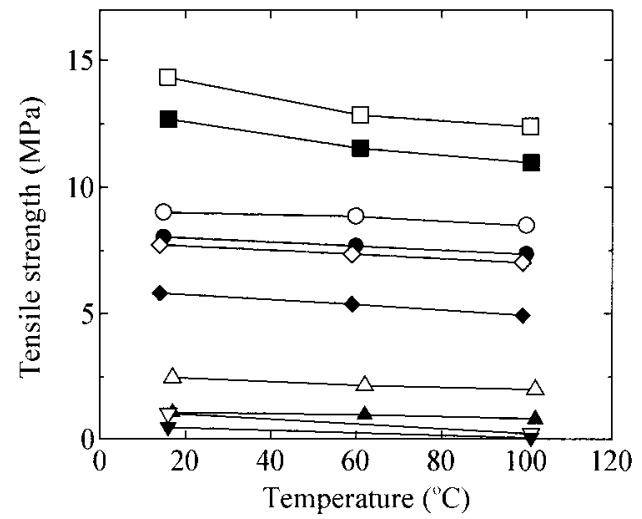

Fig. 3 Tensile strength of rocks at high temperature.
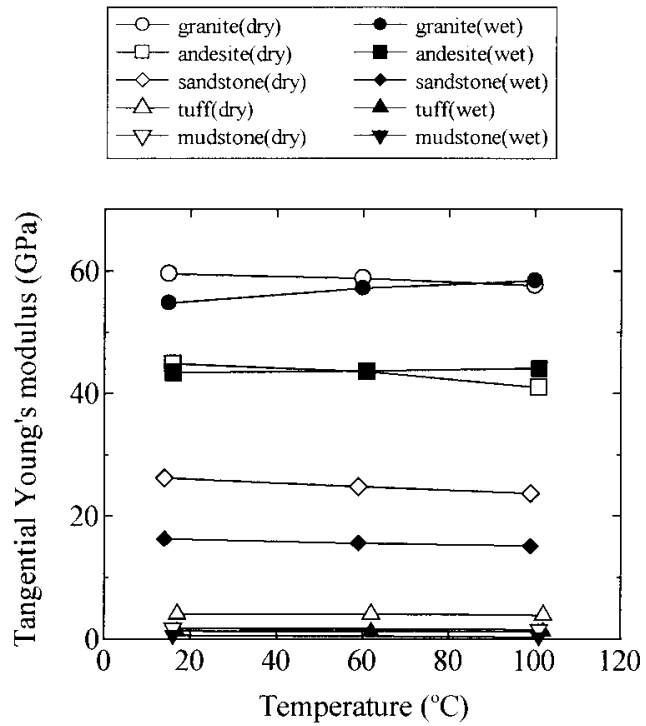

Fig. 4 Tangential Young's modulus of rocks at high temperature.

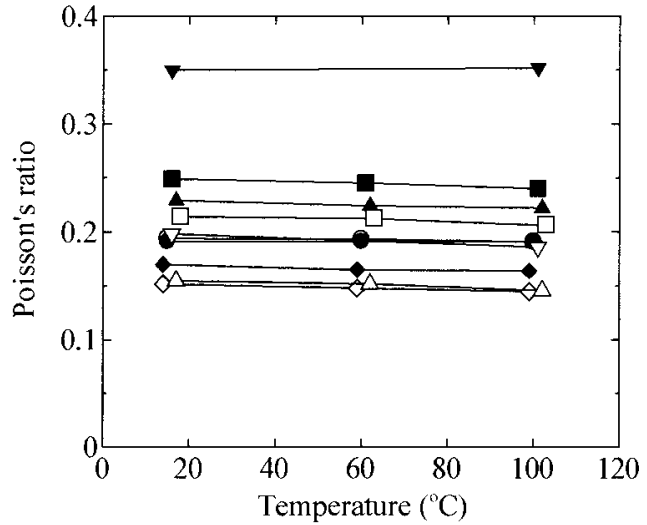

Fig. 5 Poisson's ratio of rocks at high temperature.

上昇とともに值が低下する傾向が得られたものの，花崗 岩および安山岩において Wet では温度上昇に伴う変化は ほとんどない。次にポアソン比はいずれの岩石において も Dryよりも Wet の方が大きく，その差は軟岩である凝 灰岩执よび泥岩において顕著に現れている。またいずれ の岩石に打いても温度上昇に伴い低下しているが，その 割合は小さい。

\section{$2 \cdot 4$ 弾性波伝播速度}

高温下に打ける岩石の弾性波伝播速度を測定した結果 を Fig. 6 に示す。温度の上昇と伴い值が低下している。 これは, 温度上昇により供試体の構成鉱物粒子が熱膨張 し, 組織が疎になることや，マイクロクラックの拡大が 原因であることがうかがえる。この結果は前述の圧縮強 度, 引張強度の結果を裏付けているものと考えられる。

\section{3 高温下における種々の岩石の熱物性 \\ $3 \cdot 1$ ひずみ}

各岩石の加熱による温度上昇に伴うひずみを石英ガラ ス棒を用いた比較法 ${ }^{8)}$ により測定した結果を Fig. 7 に示 す.いずれの岩石においても温度上昇に伴いひずみの值 は増加している。これは温度の上昇に伴う各岩石の構成 鉱物粒子の熱膨張によるものと，それによる隣接粒子間 のマイクロクラックの拡大，新たなマイクロクラックの 発生が原因であると考えられる。

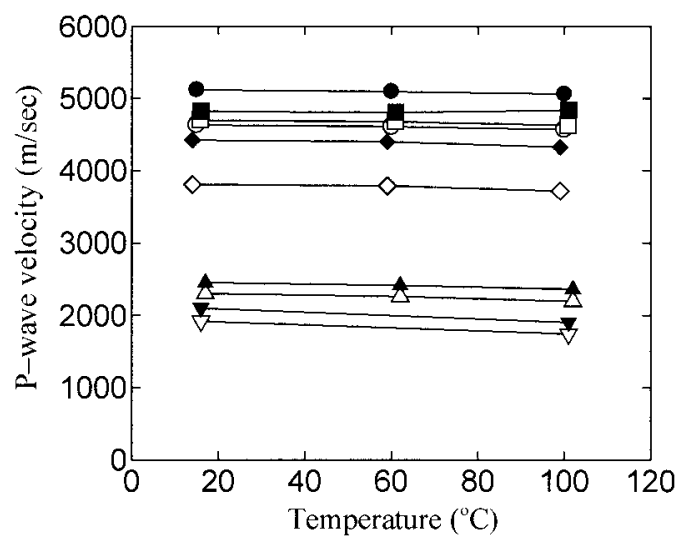

Fig. 6 P-wave velocity of rocks at high temperature. 


\begin{tabular}{|c|c|}
\hline $\begin{array}{l}-\checkmark-\text { granite(dry) } \\
\square-\text { andesite(dry) } \\
\checkmark-\text { sandstone(dry) } \\
\triangle-\text { tuff(dry) } \\
\square-\text { mudstone(dry) }\end{array}$ & $\begin{array}{l}\longrightarrow \text { - granite(wet) } \\
- \text { andesite(wet) } \\
- \text { sandstone(wet) } \\
- \text { tuff(wet) } \\
- \text { mudstone(wet) }\end{array}$ \\
\hline
\end{tabular}

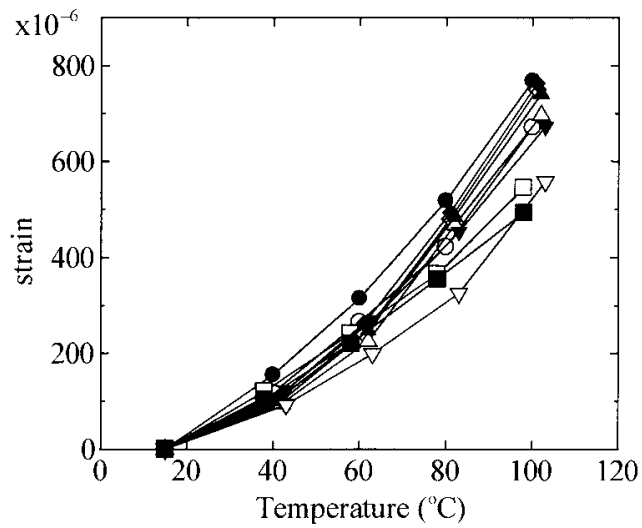

Fig. 7 Change of strain with rising temperature.

\section{$3 \cdot 2$ 熱拡散率}

要素分割法に実測值を適用させる方法 ${ }^{9)}$ で高温下にお ける熱拡散率の值を測定した。使用した供試体は $10 \times$ $15 \times 25 \mathrm{~cm}$ に成形し，Dry およびWetの状態のものを用 いて実験を行った。供試体は一次元の熱伝導が得られる ように 5 つの面を断熱材で覆い，残りの一面の表面には アルミニウム䇴を施した。 この面から $5 \mathrm{~mm}$ 間隔で $20 \mathrm{~mm}$ の位置まで 2 本ずつ合計 8 本のセンサーを平行に挿入し 温度変化を測定する。槽を設けて熱水を入れ熱源とし， 温度を $100^{\circ} \mathrm{Cに}$ に保つようにヒーターを設置した。このよ うにして得られた各測点の時間一温度曲線と式 (1)から， 熱拡散率を求めた。

$\left(\frac{\Delta X^{2}}{\kappa \Delta \tau}-2\right) U_{m, n}+U_{m+1, n}+U_{m-1, n}=\frac{\Delta X^{2}}{\kappa \Delta \tau} U_{m, n+1}$

ただし, $U_{m, n}$ : 時間 $n$ における $m$ 番目の要素の温度, $\kappa$ : 要素の熱拡散率, $\Delta X$ : 要素間隔, $\Delta \tau$ : 時間間隔, $n+1:$ 時間 $n$ から $\Delta \tau$ 後の時間

各岩石の熱拡散率を Fig. 8 に示す.今回の実験の温度 範囲内では温度に関係なくほぼ一定の值であった。また， 空隙率の小さい花崗岩および安山岩においては, Dry お よびWet ともに熱拡散率の值はほぼ同じであるが，空隙

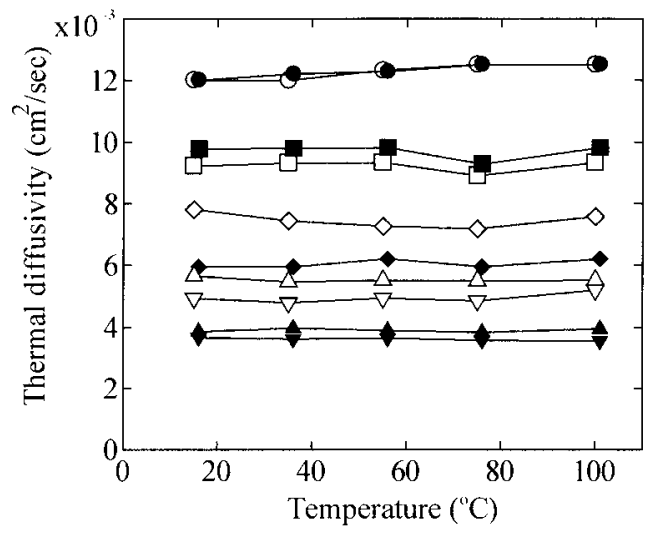

Fig. 8 Thermal diffusivity of rocks at high temperature.
率が $40 \%$ 近くある凝灰岩および泥岩においては Wet の方 が Dry よりも值が小さく，間隙水の影響を受けているも のと考えられる.

\section{$3 \cdot 3$ 比熱および熱伝導率}

高温下に打ける各岩石の比熱の測定を行った。ここで は蒸留水の満たされた断熱容器に所定温度の供試体を投 入し, 攪拌して測定した温度変化から比熱を算出した. 供試体は，熱の授受を効率よくさせるため $4 \times 4 \times 0.5 \mathrm{~cm}$ 程度に成形したものを用い，強度試験と同様に昇温速度 は $1^{\circ} \mathrm{C} / \mathrm{min}$ とし, 所定の温度に達してからの保温速度も 60 分以上とした。結果を Fig. 9 に示す。温度上昇に伴 い比熱が上昇する傾向が得られた。また，いずれの岩石 においても Dryよりも Wetの方が值は大きい。これは， 水の比熱が岩石に比べ大きいためであると考えられる.

ひずみの変化から求めた密度と熱拡散率および比熱の 值を用いて熱伝導率を見積もった。結果を Fig. 10 に示 す.いずれの岩石においても温度上昇に伴い值は増加し ている。また，各岩石について比較すると空隙率の小さ い岩石の值が最も大きく, 空隙率が大きくなると熱伝導 率の值は小さくなることがわかる.

\section{4 高温下における岩石の一軸圧縮クリープ特性}

\section{$4 \cdot 1$ 実験方法}

実験に使用した岩石は花崗岩および安山岩である。一 軸圧縮クリープ試験に使用する供試体は $\phi 2.5 \mathrm{~cm} \times$ $5.0 \mathrm{~cm}$ に成形後，真空脱気により供試体内に蒸留水を浸

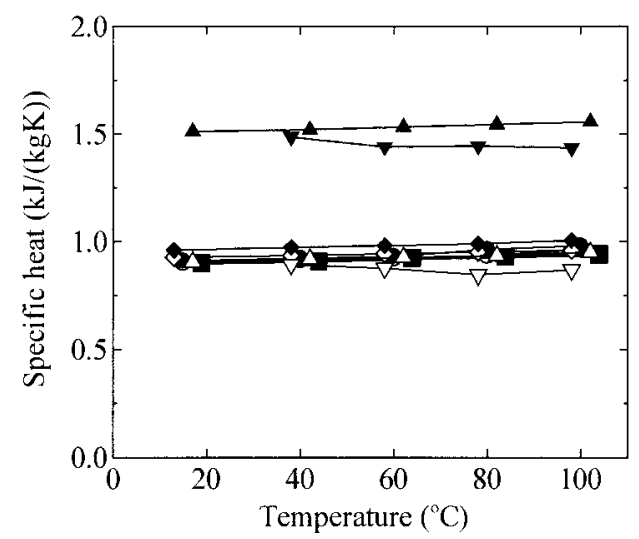

Fig. 9 Specific heat of rocks at high temperature.

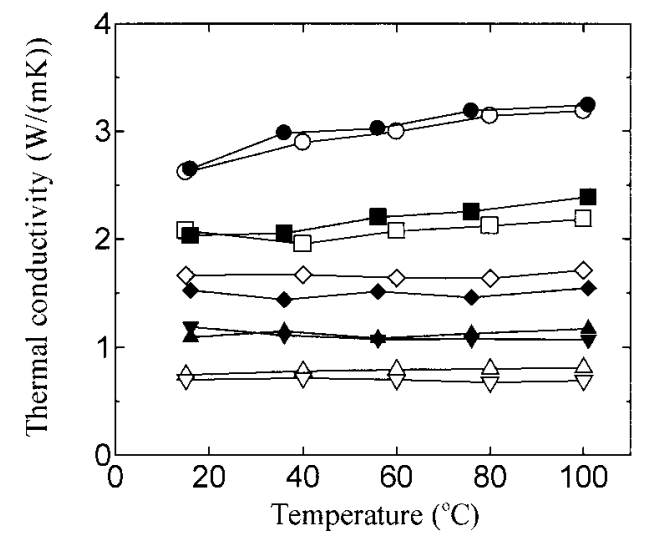

Fig. 10 Thermal conductivity of rocks at high temperature. 
潤させ湿潤状態とした。一軸圧縮クリープ試験で用いた 試験機は定格荷重 $100 \mathrm{kN}$ の油圧サーボ試験機である。高 温セル内を室内温度の蒸留水で満たし，その中に供試体 を設置し, 所要温度まで $1^{\circ} \mathrm{C} / \mathrm{min}$ 以下で加熱した。所要 温度に達した後は 60 分以上保温した。今回の実験では $20^{\circ} \mathrm{C} ， 60^{\circ} \mathrm{C}$ および $80^{\circ} \mathrm{C}$ 温度で実験を行った. クリープ 荷重はそれぞれの温度における一軸圧縮強度の $93 \%$ とし た。クリープ試験では瞬時に載荷することになっている が，実際には無理なため，今回は $1 \mathrm{MPa} / \mathrm{s} て ゙$ 載荷した. 後述する瞬間ひずみはこの条件で測定されたものである. 荷重は試験機本体に設置されたロードセルにて測定した。 ひずみは供試体に貼り付けられた 2 枚の 2 軸ひずみゲー ジにより測定した。また，比較のため試験機本体にある 変位計でも測定した。 セル内温度センサー，ロードセル， ひずみゲージ, 変位計の出力を $\mathrm{AD}$ 変換器を通して $\mathrm{PC}$ に記録した。

\section{$4 \cdot 2$ 実験結果および考察}

実験結果から典型的なクリープひずみと時間の関係の 例を Fig. 11 に示す. 温度が高くなると瞬間ひずみが小 さくなっているが，これは温度が高くなると一軸圧縮強 度が小さくなり，したがって，クリープ応力が小さくな り，また，弾性係数は温度によりあまり変化しないため である。また，破壊するまでの時間は同温度の条件にお いてもばらつきが大きかったが, 温度が高くなると破壊 までの時間が短くなる傾向がみられた。

Fig. 12 はひずみ速度と時間の関係を両対数で表した ものである。ひずみ速度が減少していく 1 次クリープ領 域では勾配が-1の直線関係になっている。この場合温度 による変化はほとんどみられない。ひずみ速度が時間の 経過とともに急増する 3 次クリープ領域は, Fig. 12 で は，クリープ曲線の勾配が垂直に近い形となり，特徴が わかりにくい。そのため，Fig. 13 のようにひずみ速度 と，破壊までの時間と経過時間との差 $\left(t_{F}-t\right)$ を両対数で あらわした。Fig. 13 では, 時間の経過は横軸の右側か ら左側に進むことなり，クリープ曲線の勾配が垂直に近 い右側の部分が 1 次クリープをあらわしている。一方, 曲線の左側部分が 3 次クリープ領域をあらわすこととな り，その特徴が比較しやすい．3 次クリープ領域ではか なり測定值に変動があるものの勾配はほぼ-1 であること がわかる，また，この場合も温度による変化はほとんど みられなかった. Fig. 14 に最小ひずみ速度と温度の関係

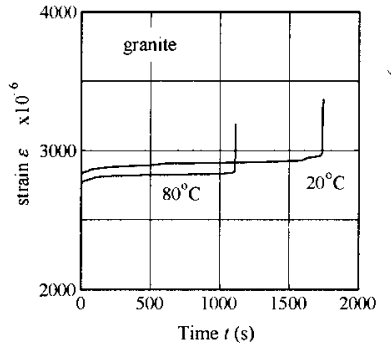

(a) granite

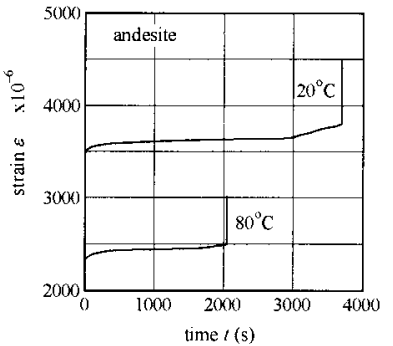

(b) antesite
Fig. 11 Strain-time curve of rocks.

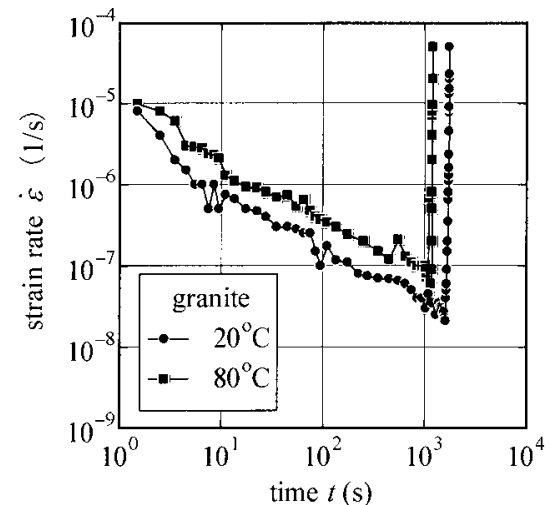

(a) granite

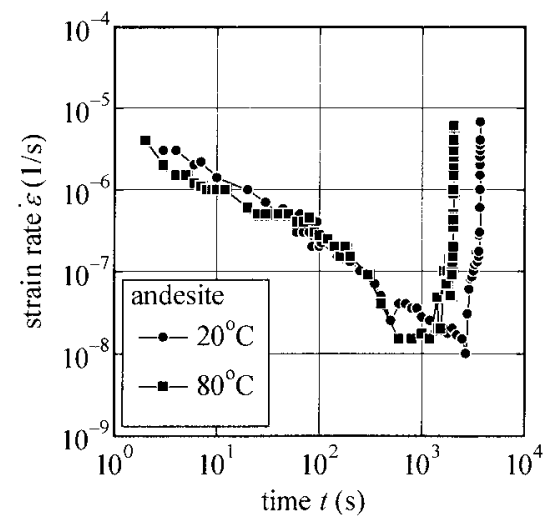

(b) andesite

Fig. 12 Strain rate-time curve of rocks.

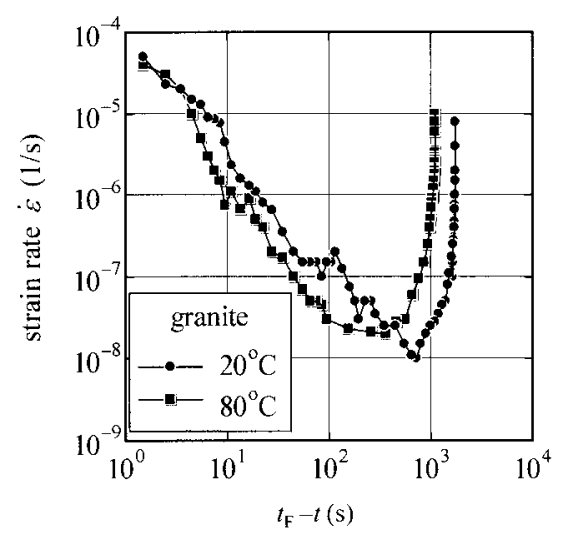

(a) granite

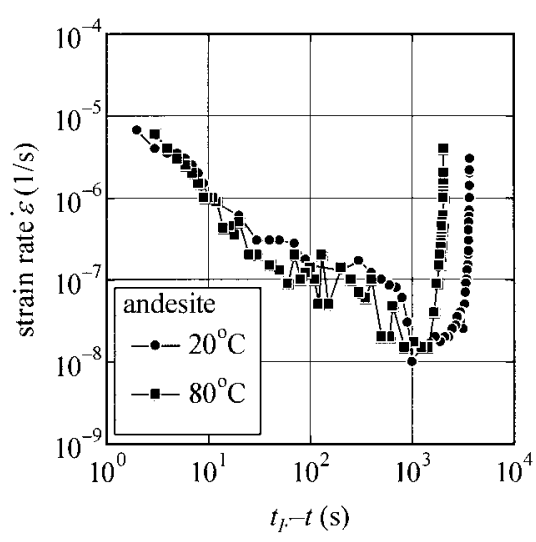

(b) andesite

Fig. 13 Strain rate-time $\left(t_{F-}-t\right)$ curve of rocks 


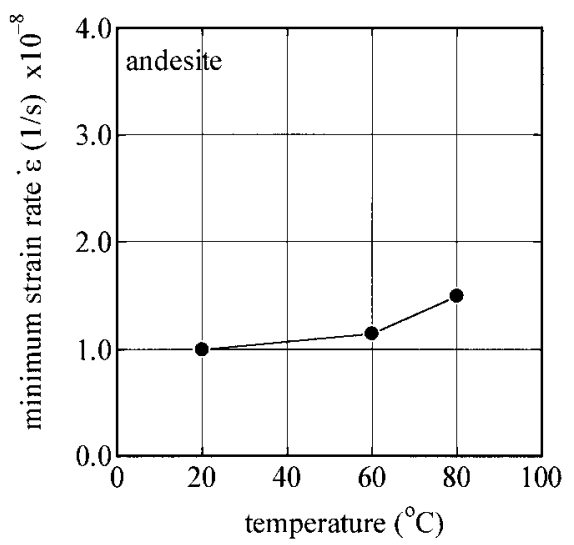

Fig. 14 Effect of temperature on strain rate.

を示す．最小ひずみ速度も測定值はばらついていたが， 概ね $20^{\circ} \mathrm{C}$ と $60^{\circ} \mathrm{C}$ では変化がなく, $80^{\circ} \mathrm{C}$ になると最小ひ ずみ速度は増加する傾向がみられた。

\section{$4 \cdot 3$ Burgers model を用いた諸定数の算定}

岩石のクリープを表すためによく用いられる力学的模 型の一つに式 (2)で表される Burgers model がある.10)

$$
\varepsilon=\sigma_{0}\left[\frac{1}{E_{1}}+\frac{1}{\mu_{1}} t+\frac{1}{E_{2}}\left\{1-\exp \left(-\frac{E_{2}}{\mu_{2}} t\right)\right\}\right]
$$

ただし， $\varepsilon:$ ひずみ, $\sigma_{0}:$ クリープ荷重, $t:$ 時間

ここでは実験結果から，式 (2)に示されるクリープに 関する諸定数の算定を試みた。結果を Table 2 に示す. $E_{1}$ の温度依存性はほとんどない。これは一軸圧縮強度試 験の結果の弾性係数と同じ傾向を示している。また，2 次クリープの特性を示す $\mu_{1}$ は温度の増加に伴いわずかな がら小さくなる。 また， $E_{2}$ もささくなる傾向を示した. $\mu_{2}$ は 1 次クリープの初期と終期では值に変動がみられた が，平均で表すとすると温度の増加に伴い低下する傾向 にある。

\section{5 結言}

本研究では, 5 種類の岩石を用い, 岩石の物理的性質 や含水状態の違いが, 高温下に打ける強度・変形特性, 熱物性およびクリープ特性に及ぼす影響を実験により求 め, 考察した. 得られた結果を要約すると以下の通りで ある。

Table 2 Physical properties of Burgers model.

\begin{tabular}{llllll}
\hline rock & $\begin{array}{l}\text { temp } \\
\left({ }^{\circ} \mathrm{C}\right)\end{array}$ & $\begin{array}{l}E_{1} \\
(\mathrm{GPa})\end{array}$ & $\begin{array}{l}\mu_{1} \\
(\mathrm{GPa} \mathrm{s})\end{array}$ & $\begin{array}{l}E_{2} \\
(\mathrm{GPa})\end{array}$ & $\begin{array}{l}\mu_{2} \\
(\mathrm{GPa} \mathrm{s})\end{array}$ \\
\hline andesite & 20 & 40.2 & $6.5 \times 10^{6}$ & $1.2 \times 10^{3}$ & $8.9 \times 10^{4}$ \\
& 80 & 40.2 & $4.2 \times 10^{6}$ & $9.0 \times 10^{2}$ & $6.4 \times 10^{4}$ \\
granite & 20 & 53.5 & $2.7 \times 10^{6}$ & $3.4 \times 10^{3}$ & $2.9 \times 10^{5}$ \\
& 80 & 52.9 & $1.9 \times 10^{6}$ & $1.5 \times 10^{3}$ & $2.2 \times 10^{5}$ \\
\hline
\end{tabular}

（1）岩石の強度は Dry よりもWetの方が小さく, 温 度の上昇に伴い低下する。また Wetでは低下の割合が大 きい. 弾性係数については花崗岩, 安山岩, 砂岩に比べ, 凝灰岩，泥岩は值が小さく，とくにWetでは高温下での 低下の割合も大きい.

（2）熱物性值については温度による影響は大きくなく 実用上はほぼ一定であるとみなせる．Dry とWet の值の 差は大きく，間隙水の影響は大きいものと考えられる. 特に空隙率の大きい凝灰岩，泥岩ではその傾向か顕著で ある。

(3) 岩石の一軸圧縮クリープ特性は $20^{\circ} \mathrm{C}$ から $80^{\circ} \mathrm{C} の$ 範囲でも温度の影響があることがわかった。今後はクリー プ応力もパラメータに加味した考察が必要であると考え られる。

\section{参 考 文 献}

1) Y. Inada and N. Kinoshita, "Laboratory experiments on strength and deformation of granite and tuff subjected to thermal hys-teresis of high and low temperatures", Journal of he Society of Material Science, Japan, Vol.48, No.4, pp.334-340 (1999).

2 ) Y. Inada and N. Kinoshita, "Thermal behavior of rock caverns affected by hysteresis of high and low temperatures", Journal of he Society of Material Science, Japan, Vol.51, No.3, pp.333-337 (2002).

3 ) Society of Material Science, Japan, "Iwa-no rikigaku", pp.37-38 (1993) Society of Material Science, Japan.

4) U. Yamaguchi and M. Miyazaki, "A study of the strength or failure of rocks heated to high temperatures”, Journal of Mining and Metallurgical Institute of Japan, Vol.86, No.986, pp.346-351 (1970).

5 ) Y. Inada and N. Yagi, "Mechanical characteristics of rocks related cooling”, Journal of he Society of Material Science, Ja-pan, Vol.28, No.313, pp.979-985 (1979).

6 ) Society of Material Science, Japan, "Iwa-no rikigaku", pp.108-110 (1993) Society of Material Science, Japan.

7 ) N. Kinoshita, T.Abe, N. Wakabayashi and T. Ishida, "Mechanical properties of rock at high temperatures", Journal of Geotechnical Engineering, No.561, III-38, pp.151-162 (1997).

8 ) Y. Inada, M. Terada and I. Ito, "On the coefficient of thermal expansion of rocks”, Suiyokwai-shi, Vol.17, No.5, pp.200-203 (1971).

9 ) Y. Inada, “Chika-no kukan riyou”, pp.101-103 (1989) Morikita Syuppan.

10) Y. Inada, “Ganban Kogaku”, p.72 (1997) Morikita Syuppan. 